\title{
Conscientious objectors seeking asylum: a comparative perspective
}

\author{
Dr Özgür H. Çınar
}

\begin{abstract}
The right to conscientious objection to military service has been a focus of interest in international human rights law for a long time. Indeed, since the 1950s both non-governmental and intergovernmental organisations have addressed the topic in a variety of contexts. This article will explore whether the right to conscientious objection is accepted as grounds for asylum in international law. In addition, it will carry out an examination of national law by focusing on domestic case-law. The article will seek an answer to the following question: should conscientious objectors have the option to seek asylum in another country? If so, what criteria should they meet? In asylum cases, are states' attitudes to the right to conscientious objection undergoing any change? Does the domestic practice in asylum cases give priority to political/diplomatic considerations or conscientious objectors' violated conscience?
\end{abstract}

KEYWORDS Conscientious objection; military service; human rights law; refugee law; national law

\section{Introduction}

Conscientious objection to military service is a way of taking a stand against war and compulsory military service for the sake of principles based on profound religious, conscience, ethical, moral, philosophical, humanitarian or similar convictions. Conscientious objectors, particularly in countries where there are no alternative services, find themselves stuck between their consciences and the compulsory duty imposed on them as citizens. Many objectors suffer accusations of cowardice and betrayal and are still subjected to discrimination and imprisonment or are forced to flee from their countries of birth.

In the United Kingdom during the First World War there were 16,000 conscientious objectors. The conscientious objection movement continued to develop during the Second World War, with more than 60,000 people becoming conscientious objectors in the UK. This figure rose to more than 200,000 during the Vietnam War. ${ }^{1}$ More recently, conscientious objection has been an issue during the 'Lebanon War', ${ }^{2}$ the 'Persian Gulf War', ${ }^{3}$ the 'Iraq War', ${ }^{4}$ and the 'Afghanistan War'.

As regards refugees, it is estimated that during the Vietnam War some 100,000 US citizens who refused to perform military service fled to countries such as Canada, France, Sweden and the UK. ${ }^{6}$ Similarly, during the apartheid period in South Africa many 
South Africans went abroad, rather than joining the army or police forces. ${ }^{7}$ Currently, at least 20 former US soldiers are claiming refugee status in Canada. ${ }^{8}$ Conscientious objectors from Turkey have also fled to other countries to claim refugee status during the conflict between the Turkish state and the PKK (Kürdistan İş̧i Partisi - Kurdistan Workers' Party), ongoing since 1984. ${ }^{9}$ As for the number of conscientious objectors trying to apply for asylum in other countries after the war began in Syria in 2012, the figure is not known. These people are being required, in performing compulsory military service, to be involved in violence and to kill. In the event of these individuals not carrying out this duty, states punish them; in reality it is their consciences that are punished. Hence, these people have fled to other countries because the right to seek asylum is set out in international law.

This article will briefly examine the right to conscientious objection at both the international (UN) and regional (especially European) level. Comprehension of the present state of the right to conscientious objection in international law is necessary in order to understand the obligations for certain countries that have yet to recognise this right. Additionally, the question will also be discussed of whether a conscientious objector from a country such as Turkey and South Korea, that does not recognise the right to conscientious objection, can seek asylum in another country. In order to do this, it will be assessed whether the right to conscientious objection is accepted as grounds for asylum in international law. Hence, a close examination will be made of the documents concerning this question in international refugee law. This article will examine the 1951 Refugee Convention, the UNHCR's Handbook on Refugee Status, the UNHCR's Guidelines on Military Service and the EU's Qualification Directive. After that, an examination will be undertaken to see whether the stances of states to the right to conscientious objection are changing in asylum cases. The question will be asked whether the domestic practice in asylum cases is to give priority to political/diplomatic considerations or conscientious objectors' violated conscience.

\section{The Overview of the right to conscientious objection to military service in international human rights law}

Initial studies regarding the right to conscientious objection to military service were put together in the 1950s. ${ }^{10}$ Today, sixty years after the first studies took place, Article 10(2) of the European Union (EU) Charter of Fundamental Rights and Article 12(1) of the Ibero-American Convention on Young People's Rights contain a provision which explicitly recognises the right to conscientious objection to military service. ${ }^{11}$ Furthermore, the UN and European mechanisms recognise this right as a legitimate expression of freedom of thought, conscience and religion, a freedom protected in all general international and regional human rights texts. ${ }^{12}$ For instance, the Human Rights Committee (HRC), in a general comment in 1989, declared the following regarding Article 18:

... The Covenant [International Covenant on Civil and Political Rights- ICCPR] does not explicitly refer to a right to conscientious objection, but the Committee believes that such a right can be derived from Article 18, inasmuch as the obligation to use lethal force may seriously conflict with the freedom of conscience and the right to manifest one's religion or belief ... ${ }^{13}$ 
In its two most recent views, the HRC has gone further, asserting that the right to conscientious objection is within the scope of the forum internum dimension of the freedom of thought, conscience and religion, and thus protected by it. ${ }^{14}$ The HRC's examination of this right in the forum internum dimension is important, as is the fact that it emphasises that a state may not intervene in a person's inner being. In other words, if this right was examined in the context of the forum externum, and if the state's aims were found to be legitimate, then its intervention would be considered valid.

Although the position of the UN's mechanisms regarding the right to conscientious objection is positive, the European mechanisms are worthy of a separate examination. Interestingly, the Parliamentary Assembly of the Council of Europe was the first European institution to recognise the right to conscientious objection in Resolution $337^{15}$ and in Recommendation 478. ${ }^{16}$ Another European mechanism, the European Parliament, in an appeal to member states in a resolution passed on 13 October 1989 expressed the following:

Calls for the right to be granted to all conscripts at any time to refuse military service, whether armed or unarmed, on grounds of conscience, with full respect for the principles of freedom and equal treatment for all members of society. ${ }^{17}$

However, the European Court of Human Rights (ECtHR) did not find any violation of 'Article 9 of the European Convention on Human Rights -ECHR- (freedom of thought, conscience and religion)' in cases concerning the right to conscientious objection until the Bayatyan judgment of 7 July 2011. ${ }^{18}$ This attitude contradicted European and UN mechanisms, meaning no consensus had previously existed regarding the right to conscientious objection. The Bayatyan judgment brought an end to these debates. The ECtHR establishing there had been a violation of Article 9 in Bayatyan v. Armenia in 2011 meant that for the first time it had evaluated the right to conscientious objection within the scope of freedom of thought, conscience and religion. The Court has subsequently found a violation of Article 9 in several other cases. ${ }^{19}$ These judgments mean that a consensus has finally been achieved in Europe, and that harmony has been established with the UN mechanisms.

\section{The right to conscientious objection and international refugee law}

As explained above, the right to conscientious objection has been specifically recognised and developed by UN and European mechanisms. However, in practice, recognition has in many cases not been implemented in domestic law such as Turkish, South Korean and in others. Therefore, the recognition of the right to conscientious objection in international law has not prevented thousands of conscientious objectors worldwide choosing to flee their home countries rather than being forced to participate in military activities in violation of their religious, political or moral convictions.

This section will seek to find an answer to the question of whether the right to conscientious objection is accepted in international law as a basis for refugee status. Hence, the Refugee Convention, the UNHCR's Handbook on Refugee Status, the UNHCR's Guidelines on Military Service as well as the EU's Qualification Directive will be examined in detail. There will also be an examination of whether the attitude taken by states to the right to conscientious objection is changing in asylum cases. Consequently, an attempt 
will be made to answer the question as to whether a conscientious objector has the option of seeking asylum in another country.

Article 14 the 1948 Universal Declaration of Human Rights (UDHR) firstly recognises the right of anyone to seek and enjoy asylum from persecution. Indeed, it states that

1. Everyone has the right to seek and to enjoy in other countries asylum from persecution. 2. This right may not be invoked in the case of prosecutions genuinely arising from non-political crimes or from acts contrary to the purposes and principles of the United Nations.

The UN mechanisms have also shown an active interest in conscientious objection as a basis for refugee status since 1978. The General Assembly ${ }^{20}$ and the Commission on Human Rights $(\mathrm{CHR})^{21}$ have both adopted several resolutions calling on Member States to consider granting all rights and benefits accorded to refugees under existing provisions to conscientious objectors. For instance, the CHR adopted Resolution $1995 / 83 .^{22}$ This resolution underlined its reference to Article 14 of the UDHR. ${ }^{23}$

In addition to the UN mechanisms' clear approach on this matter, it would be fruitful to explore as to whether the threat of persecution for refusing to perform military service is by itself sufficient grounds for a state to grant refugee status under the 1951 Convention (hereinafter 'Refugee Convention'). The Refugee Convention and other related international documents are worth examining in this regard. ${ }^{24}$

\subsection{Analysis of the sources in international refugee law}

\subsubsection{The Refugee Convention ${ }^{25}$}

According to Article 1A(2), the term 'refugee' shall apply to any person who:

... owing to well-founded fear of being persecuted for reasons of race, religion, nationality, membership of a particular social group or political opinion, is outside the country of his nationality and is unable or, owing to such fear, is unwilling to avail himself of the protection of that country; or who, not having a nationality and being outside the country of his former habitual residence as a result of such events, is unable or, owing to such fear, is unwilling to return to it.

The definition of refugee here has deliberately been kept short, in a sense granting the margin of appreciation to states. ${ }^{26}$ The Refugee Convention does not refer to conscientious objectors directly. However, it states in Article $1 \mathrm{~F}$ that:

The provisions of this Convention shall not apply to any person with respect to whom there are serious reasons for considering that: a-) he has committed a crime against peace, a war crime, or a crime against humanity, as defined in the international instruments drawn up to make provision in respect of such crimes; ...

At this juncture, it would be perverse to argue in the scope of Article 31 of the Vienna Convention that an individual's refusal to participate in combat or any act of violence on the grounds of conscience or other grounds would mean he could not gain the right to asylum. Although this is a significant starting point, as it will be discussed below whether or not the right to conscientious objection is by itself sufficient for the granting of an application for asylum.

\subsubsection{The UNHCR's Handbook on Refugee Status ${ }^{27}$}

In 1979, the UNHCR compiled the Handbook 'for the guidance of governments' in 'determining refugee status' according to the UN Convention. ${ }^{28}$ Although the Handbook is not 
a binding document, it has continued to be circulated by governments. Furthermore, governments often cite the Handbook as an authority when setting forth a definition of 'refugee'. ${ }^{29}$ Neither the Refugee Convention nor its Protocol make any mention of conscientious objection, which first appeared in the Handbook. Although it is not treated in the Handbook as a topic in its own right, it is at least mentioned as part of the discussion on 'deserters and persons avoiding military service.' 30

According to the Handbook, a deserter or draft evader is not usually deemed to be a refugee. ${ }^{31}$ Thus, Musalo emphasises that states are permitted to call up their citizens to perform military service, and for this reason the prosecution and sentencing of individuals who are seen as draft evaders is generally not deemed to be persecution. ${ }^{32}$ Even apart from this, fear of combat is not considered a sufficiently legitimate reason. ${ }^{33}$ However, on a full reading of Chapter 5, one can argue that 'deserters and persons avoiding military service' have a claim for refugee status in exceptional situations such as when: a claimant 'would suffer disproportionately severe punishment for the military offence on account of his race, religion, nationality, membership of a particular social group or political opinion'34, or 'the performance of military service would have required his participation in military action contrary to his genuine political, religious or moral convictions, or to valid reasons of conscience. ${ }^{35}$

In addition, if a person refuses on account of his political beliefs to perform military service, he has to also demonstrate that the type of military action to which he objects 'is condemned by the international community as contrary to basic rules of human conduct ...' 36

\subsubsection{The UNHCR's Guidelines on Military Service ${ }^{37}$}

In 2014 the UNCHR published a guide that concerns conscientious objectors. The aim of this guide is to 'facilitate a consistent and principled application of the refugee definition' (para 1). Volker Türk even says the following in his introduction to the guide: 'explains the legal framework for the determination of claims to refugee status of those seeking to avoid military service- whether for reasons of conscience, or because of other reasons' ${ }^{38}$ Türk also pointed out that the guide had been prepared with contributions from other stakeholders. However, the guide has been criticised by some academics. For instance, Goodwin-Gill described it as: 'a work in progress'. He added that the guide included: 'basic errors of citation, substance and presentation' and did not contain sufficient 'methodology'. He also pointed out that the approaches of national and international courts had not been examined. ${ }^{39}$ Bailliet argues that the guide is not universal, as common law jurisdiction dominates and there are no citations from the developing world. ${ }^{40}$

\subsubsection{EU's Qualification Directive 41}

The Council of the European Union adopted the Qualification Directive in April 2004. In addition to this directive being binding on EU members, it is also important as it provides minimum standards of international protection for those who need it. The European Commission replaced this directive with another in 2011: 'to address the deficiencies identified. And to ensure higher and more harmonised standards of protection' ${ }^{42}$

It was not intended that this directive would replace the Refugee Convention. However, while the intention was to provide an interpretive guide to the vague definition of refugee in this Convention, this aim was not entirely achieved. ${ }^{43}$ The Directive provides a narrow 
acceptance of conscientious objection as grounds for asylum where the applicant has suffered 'prosecution or punishment for refusal to perform military service in a conflict, where performing military service would include crimes or acts falling under the exclusion clauses ... ${ }^{44}$ It has taken a narrow approach is demonstrated by the fact that it limits the grounds to those 'extreme circumstances where the individual would be engaged in crimes against peace, war crimes, crimes against humanity, serious non-political crimes, or acts contrary to the purposes and principles of the UN'. Whereas, the UNHCR has taken a much wider approach in which refugee status is available whenever military service is contrary to 'genuine political, religious or moral convictions, or to valid reasons of conscience'. Indeed, the European Council on Refugees and Exiles stated that the Directive limited itself to 'scenarios where individuals should be required to commit war crimes or other serious crimes as part of their military service' and considered it 'unfortunate that the original wording of the Commission proposal was not retained which allowed for the reasons for the refusal to perform military service to be based on deeply held moral, religious, or political convictions' ${ }^{45}$ which would be consistent with the 'UNCHR Handbook and evolving human rights law'. ${ }^{46}$

In summary, in addition to the Refugee Convention, which is the fundamental document in international refugee law, individuals who define themselves as conscientious objectors can benefit from the Handbook, Guidelines or Directive, which are interpretive guides. However, efforts will be made below to present a critical approach to the main elements which are necessary in order to be a refugee under the Refugee Convention and other documents. Approaches in domestic courts will also be addressed in this section.

\subsection{Critical analysis of the grounds for refugee status}

\subsubsection{Persecution}

According to Article 1(A)(2) of the Refugee Convention, a conscientious objector must have 'a well-founded fear of being persecuted'. In addition, according to Article 33 of the Refugee Convention,

'it may be inferred that a threat to life or freedom on account of race, religion, nationality, political opinion or membership of a particular social group is always persecution. Other serious violations of human rights - for the same reasons - would also constitute persecution.

In spite of the importance of the word persecution, it has not been defined either in the Refugee Convention or in other international documents. In other words, there is no universally accepted definition of 'persecution'.

There are various interpretations in this regard. Paragraph 14 of the Guidelines explains in which situations persecution may be established. If:

[T] he individual is at risk of a threat to life or freedom, other serious human rights violations, or other serious harm. By way of example, disproportionate or arbitrary punishment for refusing to undertake State military service or engage in acts contrary to international law - such as excessive prison terms or corporal punishment - would be a form of persecution. Other human rights at stake in such claims include non-discrimination and the right to a fair trial right, as well as the prohibitions against torture or inhuman treatment, forced labour and enslavement/servitude. 
However, on this subject the largest contribution is made in Article 9(2) of the EU's Qualification Directive, which contains a non-exhaustive list regarding what may constitute persecution. The following are listed:

(a) acts of physical or mental violence, including acts of sexual violence; (b) legal, administrative, police, and/or judicial measures which are in themselves discriminatory or which are implemented in a discriminatory manner; (c) prosecution or punishment which is disproportionate or discriminatory; (d) denial of judicial redress resulting in a disproportionate or discriminatory punishment; (e) prosecution or punishment for refusal to perform military service in a conflict, where performing military service would include crimes or acts falling within the scope of the grounds for exclusion as set out in Article 12(2); (f) acts of a genderspecific or child-specific nature ...

As can be seen from these examples, for persecution to take place a severe violation of basic human rights, as defined in Article 1(A) of the Geneva Convention, is required. Hence, resolution 1998/77 of the CHR stated that in the event of a person being subjected to serious harassment, discrimination or violence by others, this would be accepted as persecution.

Goodwin-Gill suggests that in order to understand whether a violation of this right amounts to persecution it is necessary to examine 'the nature of the freedom threatened and the severity of the restriction'. ${ }^{47}$ The Qualification Directive supports this view thus: 'an act must be sufficiently serious by its nature or repetition as to constitute a severe violation of basic human rights. ${ }^{48}$

On this point, it is not clear what is meant by the term 'basic human rights'. It is only stated that non-derogable rights included in Article 15(2) of the ECHR are within the scope of this definition. These rights are the right to life, prohibition of torture and slavery and punishment without law. However, in Article 4(2) of the ICCPR the right to freedom of thought, conscience and religion was also included amongst non-derogable rights. At this juncture, when considered that the right to conscientious objection is a legitimate expression of this freedom, it may be said that it is of a sufficiently qualified nature. Hence, since it is in the UNHCR's Handbook, compulsory military service could be said to be possible grounds for refugee status (para. 170). This subject is mentioned in the relevant Guidelines (para. 17). It is also necessary to point out that, as mentioned above, the right to conscientious objection has been defined by the HRC within the forum internum dimension. States do not have the right to intervene in this freedom. This point may, by itself even, indicate that this right has a sufficient nature. However, some may argue that since as in the ECtHR's Bayatyan judgment the right to conscientious objection was evaluated under the forum externum dimension, states may in necessary circumstances apply restrictions based on margin of appreciation, asserting in this context that it does not have a sufficient nature. ${ }^{49}$

Despite the debate in question, as stated in Article 9(1)(a) of the Qualification Directive, the severity of the human right violation becomes an issue. In this context, does a person's being forced to perform compulsory military service, despite exercising their right to conscientious objection, amount to persecution?

As stated in Article 9(1)(a) the nature of the act of objection and whether there is repetition is important. Moreover, whether there are alternative services in a country where there is compulsory military service and, if so, what kind of services exist, and their duration, are important. Indeed, Mr Henkel, a former UNHCR Deputy Representative, stated 
that the 'UNHCR takes the view ... that, especially where no alternative to military service exists, significant punishment for refusal to perform military service, based on strong religious or moral convictions, or on political opinion, may be considered persecution. ${ }^{50}$ Furthermore, if the duration of alternative services is disproportionately longer than that of military service, it may be accepted as punishment of conscientious objectors. This may then lead to persecution.

Furthermore, conscientious objectors face constant prosecution and punishment on account of the decisions they have made. In this context it is necessary to ask whether these punishments amount to persecution within the scope of the Refugee Convention. Paragraph 167 of the Handbook is as follows:

Fear of prosecution and punishment for desertion or draft evasion does not in itself constitute well-founded fear of persecution under the definition ...

However, within the scope of Article 1(A)(2) of the Refugee Convention there are exceptional circumstances that may lead to persecution. For instance, paragraph 169 of the Handbook cites 'disproportionately severe punishment', and paragraph 18 of the Guidelines mentions 'disproportionate or arbitrary punishment' as amounting to persecution. The words 'disproportionate or discriminatory' are also used in Articles 9(2)(c) and (d) of the Directive. For instance, it may be acceptable for an individual to be punished by a government for committing the offence of desertion or draft evasion, but if the punishment imposed is increased on account of the individual's race, religion, nationality, social group membership or political opinion, then a question of discrimination will arise as the punishment has then become persecution. ${ }^{51}$

At this juncture, it is necessary to ask whether the long prison sentences handed down to conscientious objectors are discriminatory, and that if they do constitute discrimination, whether they should be accepted as persecution. For instance, the UK's Immigration Appeal Tribunal (IAT) found in the Foughali case that a long period of imprisonment (between 2 and 10 years) imposed for refusing active military service could not, of itself, be considered disproportionate. ${ }^{52}$ Hence, in the Krotov case, lawyers for the applicant did not argue this point in spite of the recommended imprisonment being between 3 and 7 years at the time in question. ${ }^{53}$

In summary, in order for conscientious objectors to gain refugee status in accordance with Article 1(A)(2) of the Refugee Convention, they have to meet additional requirements apart from the question of whether they were subjected to persecution. These requirements will be examined as below.

\subsubsection{Well-founded fear}

According to the Refugee Convention, a person making an asylum application must demonstrate they have a 'well-founded fear of being persecuted'. The European Commission, Migration and Home Affairs explained this in the following words:

The fear of persecution experienced by an applicant for international protection that is considered both genuine and objectively justifiable (e.g. because the person concerned has already been subject to persecution or serious harm, or to direct threats of such persecution or such harm, and there is no good reason to consider that such persecution or serious harm will not be repeated). ${ }^{54}$ 
From this wording it appears that the level of personal risk should be high. However, there is no mention in the Refugee Convention of what the risk level should be. According to the Handbook it should be a 'reasonable degree'. ${ }^{55}$ The Ad Hoc Committee on Statelessness and Related Problems states that a person needs to demonstrate a good reason why they are a victim of persecution or will suffer persecution. ${ }^{56}$ It is evident that it is not necessary for actual persecution to have taken place. The ordinary meaning of 'fear' implies that it is sufficient that the objector would be exposed to a risk of persecution upon return. However, previous harassment should be seen as convincing proof that the objector would be likely to become a victim of persecution if he or she returns. Indeed, Article 4(4) of the Qualification Directive states that persecution suffered previously 'is a serious indication' of a person fearing persecution. ${ }^{57}$

In addition, according to the Handbook, the word 'fear' embodies objective and subjective elements so that the applicant's personality should be taken into consideration. ${ }^{58}$ As for the Guidelines, it is stated that 'personal experience of the applicant' and 'experiences of others similarly situated' should be taken into consideration. ${ }^{59}$ Clearly, the UNHCR applies a subjective-objective approach. However, there is nothing in the Qualification Directive regarding this issue. However, a subjective approach is wide open to criticism because it is extremely difficult to be able to prove whether a person feels fear or not. It is not fair to reject the applicant's refugee status because the decision-makers simply cannot identify his/her fear. ${ }^{60}$

\subsubsection{For reasons of}

Article 1(A)(2) states that a conscientious objector's fear of persecution should be linked to at least one of the basic grounds. These five elements are listed as: 'race, religion, nationality, membership of a particular social group or political opinion'. Conscientious objectors may make a request for asylum based on an internal conflict of an ethnic nature, on account of his or her ethnic background, or due to membership of a certain religion or political group. However, in general, cases involve religious or political grounds. Whatever the grounds, consequently there must be a link between one of these elements and that which has been refused. Since in the article in question there is no clarity regarding how and on what level this link will be made, debate on this issue continues.

Some scholars have put forward the 'contributing cause' approach, asserting that: 'the Refugee Convention ground need not be the sole, or even the dominant cause of the risk of being persecuted. It need only be a contributing factor' as long as it is not 'remote to the point of irrelevance'. Others apply a different approach: 'standards of causation from other areas of law inter alia the strict but for standard from tort law'. ${ }^{61}$ The Guidelines have opted for the first approach. Qualification Directive Article 9(3) has a more relaxed attitude to the causal nexus, considering the mere existence of a link to be sufficient. ${ }^{62}$

For instance, there are several important judgments of United States of America (U.S.A) courts regarding the nexus requirement, entailing requiring proof of the prosecutor's motivation in order to satisfy the nexus requirement. ${ }^{63}$ The Canas-Segovia case, for example, is one of the fundamental cases in the U.S. case law. This case involved two brothers who applied for asylum in the U.S.A on the grounds that because of their religious beliefs as Jehovah's Witnesses they could not serve in the Salvadorean army. ${ }^{64}$ The Canas-Segovia brothers argued: 
(1) it is undisputed that his sincere religious convictions require him to refuse to serve in the military, (2) his refusal to serve is a religious practice, and (3) he is being persecuted because of his religious practice, i.e. his refusal to serve. ${ }^{65}$

At that time in El Salvador military service was compulsory for all males between the ages of 18 and 30, and the right to conscientious objection was not recognised. Moreover, according to El Salvador law, anyone evading or resisting military service was considered to be a deserter and faced a prison sentence of between one and three years, depending on circumstances. ${ }^{66}$

The Canas-Segovia brothers argued that according to Paragraph 174 of the Handbook, if an individual proves he is the citizen of a state that does not recognise the right to conscientious objection and that in the event of his not performing military service he would face persecution, the claimant should be granted refugee status. ${ }^{67}$

However, instead of paying regard to the provisions in the Handbook, the Board of Immigration Appeals decided that the conscription policy in El Salvador did not amount to persecution in accordance with the United States' Immigration and Nationality Act. The Court of Appeals firstly dismissed petitioner one's case, Jose Roberto CanasSegovia, because he abandoned his request for relief by marrying a United States citizen and returning to his country to receive his immigrant visa. The Court subsequently stated in the case of the petitioner two's submission as follows:

... the Court noted that recent case law made clear that a petitioner alleging persecution must present some evidence of the persecutor's motive. It found that petitioner two could no longer prove religious persecution since the persecuted activity could stem from either protected or unprotected causes, and petitioner two could not tie the persecution to a protected cause. Finding imputed political opinion, by definition, included an element of motive, the Court reiterated its finding in its original opinion that petitioner two was entitled to relief based on this theory. Thus, the Court remanded with instructions to dismiss petitioner one's case as moot and grant petitioner two's request for relief based on the theory of imputed political opinion. ${ }^{68}$

Because of the nexus 'proof of intent' ${ }^{69}$ requirement in the U.S.A, claims for refugee status based on conscientious objection - especially religiously-motivated conscientious objection - have not fared well. Courts have consistently ruled that the government's intent was to raise an army, not to persecute the applicant for his or her religion or belief, and that therefore nexus could not be established. ${ }^{70}$ In addition, the Courts in the U.S.A generally decided in contrast to the Handbook (para. 51), threat to life or liberty may not be sufficient to be accepted as persecution. Moreover, the Courts also stated that any violations against conscience or belief may be harder to prove than the equivalent harm of physical torture. $^{71}$

The Canadian Immigration Appeal Board (IAB), however, has granted asylum to a different Jehovah's Witness asylum claimant from El Salvador. The applicant had refused to do his military service on account of 'strongly held conscientious objection to taking human life'. ${ }^{72}$ Other, similar decisions have also been taken in Canada. ${ }^{73}$ In general the approach taken in Canada has been more humanitarian. Its focus regarding nexus analysis has examined either the intent or the effects of the law requiring military service. ${ }^{74}$ The case of Zolfagharkhani $v$ Canada involved an Iranian citizen who refused to serve in the army on the grounds that the government intended to use chemical weapons against the Kurds. The Court ruled that 'the ... definition of Convention 
refugee makes the intent (or any principal effect) of an ordinary law of general application ... relevant to the existence of persecution. ${ }^{75}$ Canadian tribunals have been consistent in applying an interpretation that considers protection of conscientious objectors who base their refusal to perform military service on religion or belief. However, when it comes to cases of political convictions, applicants have not received protection. ${ }^{76}$

After this judgment The New Zealand Refugee Status Appeals Authority (RSAA) declared in 2005 that: 'what is happening on the ground as to observance of the laws of war by parties to the conflict is key'. ${ }^{77}$ The RSAA said that no intention to persecute was needed; it was only necessary to show that the

Convention-protected ground was a "contributing cause" to the risk of persecution. Apart from moving away from requiring proof of intent, the RSAA also reaffirmed its preference for determining refugee status issues via what has become known as the "human rights approach". 78

Finally, at the time of writing (March 2020) there are only four judgments in Europe granting asylum status to conscientious objectors based on human rights approach as New Zealand. ${ }^{79}$ As indicated by these examples, very few countries show interpretations which are in harmony with the UNHCR analysis of refugee applications. ${ }^{80}$

In brief, the above-mentioned approach of the U.S. should be criticised. The purpose of the Refugee Convention is to protect persons in need, not to identify the intention of the persecutor. The motivation of the prosecutor on this issue should not be decisive. The UCHCR has also criticised this, saying that while the motivation of the prosecutor may be a factor, it is not decisive. The Guidelines on Military Service agrees with this approach, because it is often difficult to make this link ${ }^{81}$ On this subject there might be a simpler solution: If a person refuses to perform military service for political, religious, moral or genuine reasons of conscience, he has to demonstrate the sincerity of his beliefs. Furthermore, such a person has an obligation to demonstrate that military service is compulsory in his country and that the authorities do not recognise his beliefs as valid. ${ }^{82}$

\subsubsection{Military actions condemned by the international community}

As the Handbook underlines, an objector's refusal to perform military service may be based on political conviction in addition to religious or moral convictions, or reasons of conscience. It may be that a person's claim stems from disagreement with his government as regards the justification for a particular military campaign. ${ }^{83}$ The first examples that come to mind are the American conscientious objectors, numbering around one hundred thousand, who opposed the Vietnam War, or the soldiers who refused to join the South Africa military or police forces on account of their disapproval of the apartheid regime. ${ }^{84}$

Paragraph 170 of the Handbook says: '[i]t is not enough for a person to be in disagreement with his government regarding the political justification for a particular military action.' An objector on the grounds of political belief must meet another criterion from paragraph 171, that military action is 'condemned by the international community as contrary to basic rules of human conduct.' This wording would appear to exclude asylum claims from objectors in the U.S.A and other allied States during the Vietnam, Iraq and Afghanistan wars. ${ }^{85}$ In this respect, it should be noted that it is a moot point whether it is, in reality, possible for a conscientious objector to prove that a war is against of his/ her conscience. 
According to Musalo, paragraph 171 draws on the tragic experiences of the Second World War. ${ }^{86}$ Hence, Eide and Mubanga-Chipoya note that, according to the Nuremberg principles, even if a person has had no part in the decision-making process, he can still be held responsible for acts that contravene international law. Consequently, an individual, to escape individual responsibility, cannot claim he was acting on orders. ${ }^{87}$ Kurzas and other scholars also argue that this broadly accepted principle places a duty on individuals to ensure they take no part in military action if there is a probability that violations of human rights will occur. ${ }^{88}$

It is worth remembering that in times of war there are fundamentally two concepts of international law that are relevant: jus ad bellum concerns the rules on legality of the use of force as set forth in the UN Charter, while jus in bello relates to the means and methods of warfare. It is generally those in the higher echelons of government or the military who are held liable for violations of jus ad bellum, whereas for violations of jus in bello (commonly known as 'war crimes') soldiers and civilians may be held liable. This distinction has been important in determining whether a conscientious objector has acted in contravention of the 'basic rules of human conduct', since the authorities have been reluctant to consider evidence of violations of both concepts as relevant for determining refugee status. ${ }^{89}$

It is not clear from the text in the Handbook whether these 'basic rules of human conduct' include both jus in bello and jus ad bellum. However, the Guidelines, which are more up to date, confirm that the term refers to both concepts (para. 21). Although the concept of jus ad bellum is recognised, case law indicates that only high-ranking officers may make a claim for protection in violations of jus ad bellum. ${ }^{90}$

For instance, in the Hinzman and Hughey cases, ${ }^{91}$ American applicants sought refugee status in Canada. Their claim was based on the argument that U.S. military action in Iraq constituted a violation of international humanitarian law which was condemned by the international community as in contravention of basic rules of human conduct, indicating a conviction based on violations of jus ad bellum. ${ }^{92}$ They added that, on account of these violations of international humanitarian law, paragraph 171 of the Handbook stipulates that any punishment for refusing to take part in such conduct would be persecution. ${ }^{93}$ Furthermore, they maintained that it would be unfairly onerous for them to have to provide evidence of their having committed a war crime.

The Immigration and Refugee Board found that violations of jus ad bellum were 'not relevant' as regards determining acts 'contrary to basic rules of human conduct' ${ }^{94}$ The Canadian Federal Court did not accept this argument either, ruling that no evidence existed to demonstrate that the "breaches of international humanitarian law that have been committed by American soldiers in Iraq ... rise to the level of being either systematic or condoned by the state'. ${ }^{95}$ Subsequently, in 2007 the Federal Court of Appeal and the Supreme Court also dismissed their appeal. ${ }^{96}$ In the Hizman judgment, violations of jus ad bellum were deemed to be 'leadership crimes', where only those in positions capable of planning, preparing, launching and waging wars could be held responsible. ${ }^{97}$ As a 'mere foot soldier', Hinzman 'could not be held to account for any breach of international law committed by the United States'. It was only 'on the ground activities' in which he would have had involvement, that were relevant as regards paragraph $171 .{ }^{98}$ Since Hinzman as a soldier could not be considered responsible for crimes against peace, the Court found that the evaluation concerned violations of jus in bello and not jus ad bellum. As he was not able to demonstrate his participation in a war crime his appeal 
was rejected. This decision has been seen as discriminatory, since it precludes 'ordinary' soldiers from claiming conscientious objection status on the grounds of jus ad bellum. ${ }^{99}$ In 2008, in the Lebedev case, the Court dwelt on the concept of 'political expediency'. In this case it was very clear that a concern not to damage good relations with the U.S.A. Hence, a similar conclusión to the Hinzman case was arrived at. ${ }^{100}$

In the U.S.A. the requirement for intent is given priority. Refugee status is granted to applicants who claim to be conscientious objectors on religious grounds and are members of religious groups who have suffered discrimination and/or been disproportionately punished. ${ }^{101}$ However, the applications of conscientious objectors based on grounds of political beliefs, in particular selective conscientious objectors who refuse to participate in certain conflicts, have generally been rejected. For instance, in the case of Gillette $v$ United States the Court rejected the legitimacy of selective objection. ${ }^{102}$ Another important point is that in the U.S.A. the outcome of asylum applications varies according to the period. During the Cold War - for instance in 1990-91.1\% of Chinese applicants and $82.4 \%$ of applicants from the Soviet Union were approved, while only $2.5 \%$ of applications from El Salvador were successful. ${ }^{103}$ As can be seen from these figures, political considerations and foreign policy have a prominent place in asylum applications.

In addition to the U.S.A and Canada other countries also take into account the political considerations and foreign policy. For instance, in 1974 the Finnish authorities extradited two conscientious objectors (Kozlov and Varfolomeyev) back to the Soviet Union in order not to jeopardise relations. Such decisions were frequently made. For instance, in the first decade of this century Finland rejected applications made from Ukraine. ${ }^{104}$ The Norwegian Appeals Board also found the declaration made by a Russian conscientious objector who did not want to participate in military activity in Chechnya as insufficient grounds. ${ }^{105}$ It is regrettable that by questioning liability under international criminal law the standard of proof for conscientious objection has been raised, as a conscientious objector may consider himself morally responsible for his actions, regardless of any liability for them under international law. ${ }^{106}$ Musalo also emphasises that refugee authorities and courts that condemn war crimes and genocide, while refusing to grant asylum to conscientious objectors who reject taking part in these actions, could be accused of hypocrisy. ${ }^{107}$

The Guidelines appear to reject the view that only high-ranking officers can make claims based on jus ad bellum. It emphasises that 'Where an armed conflict is considered to be unlawful as a matter of international law (in violation of jus ad bellum), it is not necessary that the applicant is at risk of incurring individual criminal responsibility'. ${ }^{108}$ It is apparent that on this point the Guidelines lower the threshold, permitting all soldiers, of whatever rank, to make a claim of conscientious objection on the grounds of jus ad bellum. The Qualification Directive indicates with regard to the exclusion clause in article 12(2), mentioning both 'war crimes' and 'crimes against peace' that violations of both jus in bello and jus ad bellum constitute grounds for asylum. However, the Directive does not make clear whether it agrees with the Hinzman decision as regards excluding those of a lower rank from making claims based on violations of jus ad bellum. In order to find the answer to this question, it is necessary to look at the latest developments regarding the content and interpretation of article 9(2)(e) in Shepherd, a preliminary ruling in the Court of Justice of the European Union (CJEU) from February 2015. ${ }^{109}$

A similar argument was made by André Shepherd, who was an American soldier. He was seriously concerned about the effects on the civilian population in Iraq. On 11 April 2007 
Shepherd went Absent Without Leave (AWOL) from his Katterbach base in Germany. On 4 April 2011, Shepherd's asylum application was denied by the German Immigration Court. He appealed this decision at the Bavarian US military action Administrative Court in Munich arguing among other things that under the Directive, he should not be returned to the U.S.A, where he would face persecution. In September 2013, the German court postponed the case in order to request an advisory opinion from the CJEU. ${ }^{110}$

In this case the Advocate General (AG) of the CJEU published an opinion saying that, according to Article 9, paragraph 2, military service did not only refer to combat personnel. The opinion emphasised that all military personnel should be covered by the definition, including helicopter maintenance mechanics. As regards whether a mechanic could participate in the carrying out of war crimes, the AG admitted it was hard to reach such a conclusion, on account of national authorities having to take into consideration acts and their effects that had yet to be committed/determined. ${ }^{111}$ Thus, the CJEU referred this case back to the German Court on 25 February 2015 saying it was its duty to prove whether U.S. soldiers were committing war crimes in Iraq and whether Shepherd risked being involved in such crimes if he went'. ${ }^{112}$ The CJEU decided it was possible that war crimes had been committed. However, rather worryingly, it continues by saying that 'an armed intervention engaged upon on the basis of a resolution adopted by the Security Council offers, in principle, every guarantee that no war crimes will be committed' and that the same applies 'to an operation which gives rise to an international consensus' (para. 41). It appears that the Court is implying that when there is international consensus, there is a limited possibility that war crimes will be perpetrated, an implication that obviously raises the standard of proof required and makes it extremely difficult for protection to be granted on the grounds of article 9(2)(e). Much like in paragraph 171 of the Handbook we can observe a tendency to rely on politically influenced opinions of the international community, rather than focusing on a case-by-case assessment. ${ }^{113} \mathrm{On}$ 16 November 2016, the German Administrative Court turned down Shephard's application for asylum (European Bureau for Conscientious Objectors 2016). At the time of writing (March 2020), his appeal is still pending at the Court of Appeal.

To sum up, despite these recent clarifications, it is evident that both jus in bello and jus ad bellum are relevant as regards the assessment of claims for conscientious objection. The usual meaning of 'human conduct' may seem closer to jus in bello, as it relates to the conduct of the parties engaged in a conflict. However, since refugee law exists to protect the refugee, claims based on jus ad bellum should not be excluded on account of this wording. It should not be concluded that a person otherwise prepared to engage in combat cannot believe that it would be wrong to fight in a war that is a violation of jus ad bellum. Solely because these violations are normally seen as the responsibility of state or military leaders should not prevent conscientious objectors of all ranks from making claims based on violations of jus ad bellum. Moreover, the CJEU's suggestion that war crimes are unlikely to be committed when a military operation is supported by international consensus, demonstrates an alarming naivety regarding the conduct of armed conflicts.

At this point, a closely related question comes to mind: to what degree would a conscientious objector be required to take part in such 'inhumane' acts, and what standard of proof, if any, would be applied. Paragraph 171 of the Handbook does not refer to proof of personal or direct participation, only requiring that the applicant 'does not 
wish to be associated with' the acts in question. Unfortunately, it appears that adjudicators have misinterpreted this clause, and demand examination of the likelihood of participation in such acts. ${ }^{114}$

For instance, the Norwegian Immigration Appeals Board refused an application made by a group of Israeli soldiers, citing a lack of proof of a 'real risk' of participation in actions that violated international law. ${ }^{115}$ In the UK, the burden of proof has been lowered to 'might require' (para. 8), whilst Krotov attempted to offer a concrete test by asking whether soldiers 'may be required on a sufficiently widespread basis' to act in contravention of humanitarian norms (para. 51).

In the case of Krotov, Mr Krotov was a Russian soldier who fled the conflict in Chechnya and came to the UK to request asylum in the year 2000. In his statement his status as a selective conscientious objector is made clear in the following words:

I object to the war in Chechnya as one that is politically motivated and draw a distinction between a war that is not about the people as opposed to [an] individual fight for power. I do not object to fighting for my country say, in the situation as in the Second World War as opposed to one in which I am required to be sent into action in Chechnya and kill innocent civilians and destroy property in a reprehensible manner. ${ }^{116}$

The controversial issue in this case was the question as to whether the conflict in Chechnya had been condemned as contrary to the basic rules of human conduct by the international community. ${ }^{117}$ The IAT noted that ' $[\mathrm{t}]$ here is nothing to show that the current conflict in Chechnya has been condemned by any official international body, either as to aims or methods." ${ }^{\prime 18}$ The IAT consequently dismissed an appeal on 2 May 2002, after which Krotov went to the Court of Appeal, pointing out that paragraph 171 of the Handbook requires only that 'the international community had condemned the type of military action with which the individual did not wish to be associated as being contrary to basic rules of human conduct. ${ }^{, 19} \mathrm{He}$ also highlighted the fact that

international condemnation of a particular conflict, particularly one internal to the state concerned, may be made or withheld very much on the basis of political expediency and that the [Refugee] Convention, as a human rights instrument predicated on the requirement to provide surrogate protection for all within its scope, would be severely compromised by such an approach. ${ }^{120}$

The Court of Appeal noted that if satisfactory evidence existed, grounds under the Refugee Convention would be established. The Court added that

If a court or tribunal is satisfied (a) that the level and nature of the conflict, and the attitude of the relevant governmental authority towards it, has reached a position where combatants are or may be required on a sufficiently widespread basis to act in breach of the basic rules of human conduct generally recognised by the international community, (b) that they will be punished for refusing to do so and (c) that disapproval of such methods and fear of such punishment is the genuine reason motivating the refusal of an asylum seeker to serve in the relevant conflict, then it should find that a Convention ground has been established. ${ }^{121}$

Regarding the conflict in question in Chechnya, Lord Justice Potter stressed the importance of the judicial review in the following words:

It is (or certainly should be) the function of the Home Department to keep under review the conditions prevailing in 'hot spots' such as Chechnya in order to inform its decision in respect of an 
applicantrelying uponthoseconditions as justifying his refusal to serve. Sofaras adjudicators are concerned, it will be appropriate for the IAT by 'starred' decisions from time to time, triggered by the appeal of an applicant who relies upon up-to-date reports and other authoritative materials available as to the nature of the conflict concerned, to review such conditions and material for the purpose of providing guidance to adjudicators in subsequent cases. ${ }^{122}$

The Court of Appeal accepted the appeal and returned the case to the IAT on 11 February 2004. ${ }^{123}$ The IAT subsequently granted asylum to Krotov on 29 October $2004 .^{124}$ The Court, taking into consideration reports compiled by national and international government and non-government organisations, came to the following conclusion:

the evidence shows that breaches of the basic rules of human conduct are sufficiently widespread that it should be inferred that the Appellant was at a real risk of being required to participate in such acts in the broad sense described, that he would have been formally or informally punished for any refusal to do so and that fear of the consequences was a significant part of his claim for asylum. ${ }^{125}$

In short, to demand a high burden of proof would be contrary to the purpose of refugee law, which is to offer safeguards to individuals who have a well-founded fear of persecution. Furthermore, once it has been accepted that violations of international standards are generally the reason for refugee movement, this by itself should be sufficient grounds for those who do not want to participate in such acts, rather than raising the bar. ${ }^{126}$ Musalo also notes that the UNHCR Handbook makes clear that all the conscientious objector needs to demonstrate is that he is sincere when he refuses to take part in human rights violations or abuses, without having to provide absolute proof of his own personal participation in such violations. ${ }^{127}$ It is unfortunate that states and international bodies have demanded an evidence in cases of conscientious objection. ${ }^{128}$ For instance, the Guidelines seek a 'reasonable likelihood' of participation in contraventions of international law, threshold higher than in Sepet and Krotov. ${ }^{129}$ In other words, the Guidelines require a certain degree of proof of personal participation, even though there is no requirement mentioned in paragraph 171 of the Handbook. According to the Guidelines, protection can only be provided to persons whose duties could 'sufficiently directly' entail their participation in war crimes. ${ }^{130}$ The CJEU also confirms a similarity to the Guidelines in the case of Shepherd. ${ }^{131}$ The Guidelines also emphasise that in the event of more indirect participation, a claim of persecution is unlikely to succeed without 'additional factors', hereafter a link between the role of the applicant and 'foreseeability of or contributions to' the violations of international law. ${ }^{132}$

The Guidelines accept the conscience of the applicant is a potentially decisive factor in a claim for protection for those indirectly involved in war crimes. It is here that the consequences of the lack of recognition of the applicant's conscience in the Directive become apparent. Several courts have rejected claims of selective objectors, in particular, on account of concluding that the high standards set forth in paragraph 171 have not been met in cases where 'political opinion' has been the Convention ground chosen by conscientious objectors. The convictions and sincerely held beliefs of the objector are in this way overshadowed by this linking of the objection to a political opinion and an external assessment regarding the international community's view of military action. Perhaps adjudicators are attaching too much importance to the conditions set out in paragraph 171 , which are, after all, only an interpretative guide to article $1 \mathrm{~A}(2){ }^{133}$ 
In this respect, there is also another issue worthy of attention in these decisions. The right of asylum for individuals who refuse to perform military service on account of international condemnation of a conflict seems to be undermined by the reluctance of national and international bodies to reach judgments against other states regarding such conflicts. There should be serious concern about the fact that decisions are frequently influenced by political/diplomatic relations or economic reasons rather than by international norms. This leads to national governments being disinclined to use condemnatory language for fear of upsetting such relations. ${ }^{134}$ The cases mentioned above highlight this state of affairs, as do instances of American objectors who sought asylum during the Vietnam War. In most of these cases, states opted to hand out temporary residence permits rather than granting asylum under the Refugee Convention. However, American deserters and draft evaders received 'humanitarian asylum' in Sweden ${ }^{135}$, a situation that caused political problems between Sweden and the U.S.A. ${ }^{136}$

As a result of political/diplomatic relations or economic reasons Courts have generally used similar wording in their decisions, declaring that 'there is no evidence that violations of international humanitarian law have been committed by the [American, British, Russian, Turkish] soldier in [Iraq, Afghanistan, Chechnya, Turkey etc.]. ${ }^{137}$ Indeed, Lippman also points out that asylum decisions are usually linked to political expediency. ${ }^{138}$ Similarly, Marcus states as follows:

The ambiguity of the Handbook, the lack of an independent internationally-based inquiry into asylum requests, and the domestic nature of asylum proceedings leaves states the ultimate authority in asylum decisions ... The decision to grant asylum is largely determined by the political relationship between the state the resister seeks to escape and the state in which the resister seeks refuge. Asylum decisions also reflect states' positions toward the importance of recognising conscientious objection as an international human right. ${ }^{139}$

\section{Conclusion}

The typical practice in asylum cases has been to give priority to political/diplomatic considerations, ignoring the pertinent fact that conscientious objectors would suffer persecution if they refused to violate their conscience by performing military service. ${ }^{140}$ The judgments referred to above demonstrate clearly that domestic courts have evaluated applicants' refusals to join the military on political grounds, but have failed to take into consideration the key issue of conscience. However, there is no doubt that when a person is obliged to perform military service contrary to his genuine belief, the freedom of conscience is violated in the public sphere. Hence, if a person is opposed to the military actions of the state of which he is a citizen, he will find himself on the horns of a dilemma as regards his conscience and the possible punishment consequent on his opposition. As any punishment would constitute a violation of his conscience, it is wrong to put asylum seekers in a position where they have to make a choice between imprisonment and violating their conscience. ${ }^{141}$

It is noteworthy that Articles 18 of the UDHR and ICCPR and Article 9 of the ECHR specifically recognise the right to freedom of thought, conscience and religion, although none of these documents refer explicitly to the right to conscientious objection. In contrast, this right has been discussed by UN mechanisms since the 1950s and the UN and the European (e.g. ECtHR, EU) mechanisms now recognise the right to freedom of 
conscientious objection as a legitimate exercise of the right to freedom of thought, conscience and religion. ${ }^{142}$ The right to conscientious objection has a close relationship to the forum internum and forum externum dimensions of the freedom of thought, conscience and religion. ${ }^{143}$ In 2011 the HRC published its latest opinion regarding the right to conscientious objection, ${ }^{144}$ addressing this right with reference to the forum internum aspect. The HRC's recognition of the forum internum aspect makes it absolutely clear that states have no right to intervene in the inner being of conscientious objectors, whatever the circumstances. In this latest opinion the HRC emphasised the fact that an individual alone has the right to determine his/her own destiny. As a result of this conclusion, the right to conscientious objection as part of the freedom of thought, conscience and religion is now recognised as an absolute and non-derogable right.

In conclusion, it is the case that international recognition of the right to conscientious objection itself renders necessary the granting of asylum to conscientious objectors. The Refugee Convention should be seen as a living instrument and interpreted in the light of contemporary circumstances. ${ }^{145}$ Indeed, the Refugee Convention declares that any attempts with the purpose of forcing individuals to act contrary to their beliefs, such as torture or incarceration, should be deemed persecution. ${ }^{146}$ Apart from the Refugee Convention, as can be seen in the other instruments which were examined above, although there is not complete harmony amongst them, in the event of the right to conscientious objection not being accepted in their own countries, the right to asylum should be recognised. The Handbook, the Guidelines and the EU's Qualification Directive support such a solution. A radical change is needed in the practice of many countries where priority is given to political/diplomatic considerations rather than to compliance with international norms. Hence, this radical change is in fact entirely interrelated to the obligation arising from international law of states to protect the rights and freedoms of everyone in their jurisdictions (Article 2 of ICCPR; Article 1 of ECHR). There exists an obligation for states to protect these rights and freedoms in a practical and effective way in accordance with the standards of international law. ${ }^{147}$ In this context it is evident that such a change in practice would be important as regards international mechanisms such as the EU, Council of Europe and UN having a deterrent effect on member states.

\section{Notes}

1. Peace Pledge Union, Refusing to Kill - Conscientious Objection and Human Rights in the First World War (Peace Pledge Union, 2006), 4.

2. See Shein and others v. Minister of Defence, P.D. 48(3) 393 (1984).

3. See United States v. Cook, 92-0053 (1992).

4. See Hauptmann v. Wehrdisziplinaranwalt, 2nd Military Service Division (Wehrdienstsenat) of the Federal Administrative Court (Bundesverwaltungsgericht), BverwG 2 WD 12.04, 21 June 2005.

5. See Watson v. Geren, 569 F.3d 115 (2009).

6. J. Walch, Aid to Military Refugees: the case of Sweden (War Resistance 3, 1974), 27-8.

7. A. Smail, The Church and the Military in South Africa (London: Committee on South Africa War Resistance, 1981), 19.

8. War Resisters Support Campaign, 'War Resisters in Canada', War Resisters Support Campaign, http://www.resisters.ca/resisters_stories.html (accessed December 19, 2019).

9. See, for example, Sepet and Bülbül v. Secretary of the State for the Home Department; New Zealand Refugee Status Appeals Authority, Refugee Appeal no. 75378/05, 19 October 2005. 
10. See e.g. Statement of Service Civil International, UN Doc. E/CN.4/NGO/1 Add. 1(1950).

11. Charter of Fundamental Rights of the European Union, adopted on 7 December 2000, 2000/ C 364/01, OJ C 83 of 30 March 2010 and Ibero-American Convention on Young People's Rights, adopted on 10/11 October 2005, entered into force 1 March 2008.

12. See e.g. Article 18 of the Universal Declaration of Human Rights (adopted on 10 December 1948, UNGA. Res.172 A (III)); Article 18 of the International Covenant on Civil and Political Rights (adopted on 16 December 1966, entered into force on 23 March 1976, 999 UNTS 171); Article 9 of the European Convention on Human Rights (adopted on 4 November 1950, entry into force on 3 September 1953, ETS. 5).

13. HRC, General Comment No. 22, 'The Right to Freedom of Thought, Conscience and Religion', UN Doc. CCPR/C/21/Rev.1/Add.4, 30 July 1993, para. 11.

14. Min-Kuy Jeong et. al. v. the Republic of Korea, 27 April 2011, Human Rights Committee, Nos. 1642 to 1741/2007; Cenk Atasoy and Arda Sarkut v. Turkey, 29 March 2012, Human Rights Committee, Nos. 1853/2008 and 1854/2008.

15. PACE, Resolution No. 337 (1967), 26 January 1967.

16. PACE, Recommendation No. 478 (1967), 26 January 1967.

17. European Parliament, Resolution on Conscientious Objection and Alternative Civilian Service, 13 October 1989, Doc. A3-15/89, 1989 O.J. (C 291) 122, 11 (1989), para. G/1.

18. See e.g. Grandrath v. the Federal Republic of Germany, 10 Y.B. Eur. Conv. on H.R. 626(1966), European Commission of Human Rights, No. 2299/64; Autio v. Finland, 72 Eur. Comm'n H.R. Dec. \& Rep. 245 (1990), European Commission of Human Rights, No. 17086/90; Bayatyan v. Armenia, 7 July 2011, European Court of Human Rights (Grand Chamber), No. 23459/03.

19. See e.g. Erçep v. Turkey, 22 November 2011, European Court of Human Rights, No. 43965/ 04; Bukharatyan v. Armenia, 10 January 2012, European Court of Human Rights, No. 37819/ 03; Çăglar Buldu and Others v. Turkey, 3 June 2014, European Court of Human Rights, No. $14017 / 08$

20. In 1978 the General Assembly adopted a resolution recognising the right of all persons to refuse to serve in military or police forces used to enforce apartheid in South Africa (Resolution no. 33/165).

21. In 1998, the CHR adopted a resolution (Resolution no. 1998/77, para. 7) concerning the right to asylum for conscientious objectors. It read as follows: '[The CHR encourages] States, subject to the circumstances of the individual case meeting the other requirements of the definition of a refugee as set out in the 1951 Convention relating to the Status of Refugees, to consider granting asylum to those conscientious objectors compelled to leave their country of origin because they fear persecution owing to their refusal to perform military service when there is no provision, or no adequate provision, for conscientious objection to military service.'

22. CHR, Resolution no. 1995/83, 8 March 1995, para. 1.

23. Ibid., the twelfth sentence of preambular paragraph.

24. J. Rehman, International Human Rights Law, 2nd ed. (Harlow: Pearson, 2010), 644.

25. See Convention relating to the Status of Refugees, 189 UNTS 150, adopted on 28 July 1951, entered into force on 22 April 1954 and 1967 Protocol Relating to the Status of Refugees, 606 UNTS 267, adopted on 31 January 1967, entered into force on 4 October 1967.

26. Andreas Zimmermann (Ed.), The 1951 Convention Relating to the Status of Refugees and its 1967 Protocol- A Commentary (Oxford: Oxford University Press, 2011), 299.

27. 'Handbook on Procedures and Criteria for Determining Refugee Status under the 1951 Convention and the 1967 Protocol relating to the Status of Refugees' was published by the Office of the United Nations High Commissioner on Refugees in 1979. It was re-edited in 1992, HCR/IP/4/Eng/REV.1.

28. The Handbook, foreword (iv).

29. See K. J. Kuzas, 'Asylum for Unrecognized Conscientious Objectors to Military Service: Is There a Right Not to Fight?', Virginia Journal of International Law 31 (1990-1991): 455. See also Report on the 30th Session of the Executive Commission of the High Commissioner's Programme, paras. 68, 72(a)\&72(h), A/AC.96/572 (1979); Report on the 31st 
Session of the Executive Commission of the High Commissioner's Programme, para. 36, A/ AC.96/588 (1980).

30. See Chapter 5 of the Handbook, entitled 'Special Cases'.

31. Paragraph 168 states: 'A person is clearly not a refugee if his only reason for desertion or draft-evasion is his dislike of military service or fear of combat. He may, however, be a refugee if his desertion or evasion of military service is concomitant with other relevant motives for leaving or remaining outside his country, or if he otherwise has reasons, within the meaning of the definition, to fear persecution.'

32. K. Musalo, 'Claims for Protection Based on Religion or Belief'. International Journal of Refugee Law 16 (2004): 208.

33. The Handbook, para., 167-8.

34. Ibid., para., 169.

35. Ibid., para., 170.

36. Ibid., para., 71.

37. Guidelines on International Protection No. 10, HCR/GIP/13/10/Corr. 1. 12 November 2014.

38. Volker Türk and Alice Edwards, 'Introductory Note to Guidelines on International Protection No. 10 on Claims to Refugee Status related to Military Service', International Journal of Refugee Law 27 (2015), 167.

39. Guy S Goodwin-Gill, 'The Dynamic of International Refugee Law', International Journal of Refugee Law 25 (2014): 658.

40. Cecilia M. Bailliet, 'National Case Law as a Governor of International Refugee Law: Rectifying an Imbalance Within UCJCR Guidelines on International Protection', Emory International Law Review 29 (2015): 2063.

41. EU Qualification Directive 2004/83, 29 April 2004.

42. Directive 2011/95/EU of the European Parliament and of the Council of 13 December 2011 on standards for the qualification of third-country nationals or stateless persons as beneficiaries of international protection, for a uniform status for refugees or for persons eligible for subsidiary protection, and for the content of the protection granted (recast). See also European Commission, Proposal for a Directive of the European Parliament and of the Council on minimum standards on procedures in Member States for granting and withdrawing international protection (Recast), COM (2009) 554/4, p. 5.

43. Ingeborg Skancke Karlsnes, 'Under What Circumstances May Conscientious Objection to Military Service bea Ground for Refugee Status?'(Master's thesis, Bergen University, 2015), 19.

44. The Council of the European Union, Council Directive 2004/83/EC, 'On Minimum Standards for the Qualification and Status of Third Country Nationals or Stateless Persons as Refugees or as Persons who Otherwise Need International Protection and the Content of the Protection Granted', Articles 9(2)(e) and Article 12(2), 2004 O.J. (L 304)12.

45. European Council on Refugees and Exiles, 'European Council on Refugees and Exiles Information Note on the Council Directive 2004/83/EC', IN1/10/2004/ext/CN, 29 April 2004.

46. K. Musalo, 'Conscientious Objection as a Basis for Refugee Status: Protection for the Fundamental Right of Freedom of Thought, Conscience and Religion', Refugee Survey Quarterly 26 (2007): 76.

47. Guy S. Goodwin-Gill and Jane McAdam, The Refugee in International Law, 3rd ed. (Oxford: Oxford University Press, 2007), 92.

48. The Qualification Directive, Article 9/1(a).

49. Goodwin-Gill, supra note 39, 660.

50. See Letter from Joachim Henkel (30 January 1986) to Karen Musalo in K. Musalo, 'Swords into Ploughshares: Why the United States Should Provide Refuge to Young Men Who Refuse to Bear Arms for Reasons of Conscience', San Diego Law Review 26 (1989): 857.

51. Ibid., 856.

52. Foughali v. Secretary of State for the Home Department, [2000] 00/TH/01513/IAT. See also United Kingdom Border Agency, 'Asylum Policy Instruction on Military Service and Conscientious Objection'. Available at http://www.ukba.homeoffice.gov.uk/sitecontent/ documents/policyandlaw/asylumpolicyinstructions/apis/militaryservice.pdf?view=Binary (accessed December 19, 2019). 
53. Krotov [AK (Russia-Chechnya deserter)] v. Secretary of State for the Home Department, [2002] C1/2002/1537/IATRF, para. 6.

54. See Migration and Home Affairs, 'Well-founded fear of persecution', https://ec.europa.eu/ home-affairs/what-we-do/networks/european_migration_network/glossary_search/wellfounded-fear-persecution_en (accessed December 19, 2019).

55. The Handbook, para. 42.

56. UN Doc E/1618 AND E/AC/32/5 (1950), p. 39.

57. Karlsnes, supra note 43, 28.

58. The Handbook, para., 40-1.

59. The Guidelines, para., 13.

60. Karlsnes, supra note 43, 28-9; See also James Hathaway et. al., The Law of Refugee Status, (Cambridge: Cambridge University Press, 2. Edition, 2014), 96.

61. Ibid., 30. See also University of Michigan Law School, 'International Refugee Law: The Michigan Guidelines on Nexus to a Convention Ground', Michigan Journal of International Law 23 (2002), para. 13.

62. The Directive, Article 9(3).

63. Karlsnes, supra note $43,30$.

64. Canas-Segovia v. Immigration and Naturalization Service, No. 88-7444, 970 F.2d 599; 1992 U.S. App. LEXIS 15505; 92 Cal. Daily Op. Service 6088; 92 Daily Journal DAR 9629 (9th Circuit, July 10, 1992).

65. Ibid., p. 2.

66. Canas-Segovia v. Immigration and Naturalization Service, Board of Immigration Appeals, No. 3074 (September 18, 1988), p. 711.

67. 'The genuineness of a person's political, religious or moral convictions, or of his reasons of conscience for objecting to performing military service, will of course need to be established by a thorough investigation of his personality and background.'

68. Canas-Segovia v. Immigration and Naturalization Service, 9th Circuit, p. 1.

69. Nexus test is 'the requirement that a person's well-founded fear of being persecuted be 'for reasons of' one of the five enumerated grounds in Article $1 \mathrm{~A}(2)$ of the Refugee Convention: race, religion, nationality, membership of a particular social group, or political opinion' (For further info see M. Foster, 'Causation in Context: Interpreting the Nexus Clause in the Refugee Convention', Michigan Journal of International Law 23 (2002): 265-340). 266.

70. K. Musalo, 'Claims for Protection Based on Religion or Belief: Analysis and Proposed Conclusions', UNHCR Legal and Protection Policy Research Series, 2002, http://www.unhcr.org/ protect/PROTECTION/3e5f6ad12.pdf (accessed December 19, 2019), 39.

71. Foster, supra note $69,574,575$.

72. Ramirez $v$. Canada (Minister of Employment and Immigration), Immigration Appeal Board, No. V86-6161, 5 May 1987, p. 4.

73. See, for example, Abarca $v$. Canada (Ministry of Employment and Immigration), Immigration Appeal Board, No. W86-4030-W, 21 March 1986.

74. Musalo, supra note 46, 73.

75. Zolfagharkhani v Canada (Minister of Employment and Immigration), [1993] 3 F.C. 540, Canada: Federal Court of Appeal, 15 June 1993.

76. Musalo, supra note 46, 73.

77. Refugee Status Appeals Authority, Refugee Appeal no. 75378/05, 19 October 2005, para 87.

78. Ibid., para. 43.

79. Cour Nationale Du Droit d'Asile (National Asylum Court) in France granted Yeda Lee from South Korea, and Yunus Özdemir from Turkey asylum in 2014. Moreover, Okan Kale and Ugur Bilkay were granted asylum status in Italy.

80. A.C. Helton, 'Resistance to Military Conscriptionon or Forced Recruitment by Insurgents as a Basis for Refugee protection: A Comparative Perspective', San Diego Law Review 29 (1992): 588-94.

81. The Guidelines, para 48.

82. Musalo, supra note 46,71 . 
83. See, for example, the cases of Sepet and Bülbül and Krotov.

84. Walch, supra note 6,27-8; A. Eide \& C. Mubanga-Chipoya, Conscientious Objection to Military Service, (New York and Geneva: UN Publication, 1983), para. 126.

85. Kuzas, supra note 29, 460.

86. Musalo, supra note 50,870 .

87. Eide and Mubanga-Chipoya, supra note 84, paras 51 and 128.

88. Kuzas, supra note 29, 461; Musalo, supra note 50, 870; The Lawyers Committee for International Human Rights (1980) Conscientious Objection as a Human Right., (New York: Lawyers Committee for International Human Rights, 1980), 9; C. D. de Jong, The Freedom of Thought, Conscience and Religion or Belief in the United Nations (1946-1992), (Antwerpen/Groningen/Oxford: Intersentia, 2000), 178-9.

89. Karlsnes, supra note 43,36 .

90. Ibid., 36.

91. Hinzman and Hughey v. Canada, A-182-06, A-185-06, 30 April 2007.

92. Hinzman and Hughey v. Canada (Minister of Citizenship and Immigration), 2007 FCA 171, 30 April 2007.

93. Ibid., paras. 25 and 30.

94. Hinzman v Immigration and Refugee Board, File TA4-01429, Immigration and Refugee Board of Canada (16 March 2005) para. 10.

95. Hinzman and Hughey v. Canada (Minister of Citizenship and Immigration), 2006 FC 420, 31 March 2006, para. 189.

96. Hinzman and Hughey, 2007 FCA 171, 30 April 2007 and Supreme Court of Canada, 50078 (S.C.C.), 15 November 2007.

97. Ibid. para 142 .

98. Ibid. para. 188 .

99. Cecilia M. Bailliet, 'Assessing Jus ad Bellum and Jus in Bello Within the Refugee Status Determination Process: Contemplations on Conscientious Objectors Seeking Asylum', Georgetown Immigration Law Journal 20 (2005-2006): 373.

100. (Lebedev v Canada (Minister of Citizenship and Immigration) (2007) FC 728, (2008) 2 F.C.R. $585(\mathrm{FC}))$.

101. Canas-Segovia v. Immigration and Naturalization Service, 970 F.2d 599, 601 (9th Cir. 1992); Ilchuk v. Att. Gen. of the US, 434 F. 3d 618 (3rd Cir. 2006) and Ghebremedhin v. Ashcroft, 385 F. 3d 1116 (7th Cir. 2004)

102. 401 U.S. 437 (1971), paras. 437, 439.

103. Corii D. Berg, 'The Conscientious Objector Applying for Political Asylum: Forced to Bear Arms and the Brunt of M.A.A26851062 v. INS', Loyola of Los Angeles International and Comparative Law Review 139 (1991): 163-4.

104. 'Finland's history of forced returns: Deporting Conscientious objectors and a sedated family', Yle Uuutiset, 13.04.2017, https://yle.fi/uutiset/osasto/news/finlands_history_of_forced_returns_deport ing_conscientious_objectors_and_a_sedated_family/9564745 (accessed December 19,2019).

105. Bailliet, supra note 99, 356.

106. Ibid

107. Musalo, supra note 50, 870 .

108. The Guidelines, para. 23

109. Andre Lawrence Shepherd v Bundesrepublik Deutschland, C-472/13, [2015]. See also Karlsnes, supra note 43, 37-8.

110. European Bureau for Conscientious Objectors, Annual Report: Conscientious Objection to Military Service in Europe 2014, https://static1.squarespace.com/static/54c00acde4b022a 64cd0266b/t/5506eedfe4b0b39d3c23b846/1426517727250/2014-EBCO-REPORT-EUROPE .pdf (accessed December 19, 2019).

111. Press Release, Court of Justice, No. 147/14.

112. German Court Rejects US Soldier's Asylum Application, Deutsche Welle, 17 November 2016, http://www.dw.com/en/german-court-rejects-us-soldiers-asylum-application/a-3642816 5 (accessed December 19, 2019). 
113. Karlsnes, supra note 43, 39.

114. Ibid., 142.

115. Ibid., 143.

116. Krotov [AK (Russia-Chechnya deserter)] v. Secretary of the State for the Home Department, [2004] EWCA (Civ) 69, 2004 1. W.L.R. 1825, para. 2 (citing Krotov [AK (Russia-Chechnya deserter)] v. Secretary of State for the Home Department, [2002] C1/2002/1537/IATRF, para. 23).

117. Ibid., [2004] EWCA (Civ) 69, para. 9.

118. Ibid., [2004] EWCA (Civ) 69, para. 11 (citing Krotov [AK (Russia-Chechnya deserter)] v. Secretary of State for the Home Department, [2002] C1/2002/1537/IATRF, para. 4).

119. Ibid., [2004] EWCA (Civ) 69, para. 22.

120. Ibid.

121. Ibid., para. 51.

122. Ibid., para. 53.

123. Ibid., para. 54.

124. Krotov [AK (Russia-Chechnya deserter)] v. Secretary of the State for the Home Department, [2004] UKIAT 00294, 29 October 2004.

125. Ibid., p. 31.

126. Karlsnes, supra note $43,40$.

127. Musalo, supra note 50, 869 .

128. Musalo, supra note 46, 76; Bailliet, supra note $99,367$.

129. The Guidelines, para. 26.

130. The Guidelines, para. 36-8.

131. Andre Lawrence Shepherd v Bundesrepublik Deutschland, para. 38.

132. Ibid., para. 29; See also Karlsnes, supra note 43, 40-1.

133. Karlsnes, supra note 43, 41-2.

134. Bailliet, supra note 99,354 .

135. M.A. 899 F.2d, paras. 312 and 317.

136. Kuzas, supra note $29,459$.

137. For example, Krotov, [2004] EWCA (Civ) 69, 2004 1. W.L.R. 1825, para. 2 (citing Krotov, [2002] C1/2002/1537/IATRF, para. 25).

138. M. Lippman, 'The Recognition of Conscientious Objection to Military Service as an International Human Right', California Western International Law Journal 21 (19901991): 40-1.

139. E. N. Marcus, 'Conscientious Objection as an Emerging Human Right?', Virginia Journal of International Law 38 (1997-1998): 538.

140. Lippman, supra note 138, 40-1; Baillet, supra note 99, 354.

141. Goodwin-Gill \& McAdam, supra note 47, 114.

142. For example, HRC, General Comment no. 22 and the judgment of Yeo-Bum Yoon and Mr Myung-Jin Choi v. the Republic of Korea, Communication nos: 1321/2004 and 1322/2004, 3 November 2006, CCPR/C/88/D/1321-1322/2004.

143. See, for example, Yeo-Bum Yoon and MrMyung-Jin Choi v. the Republic of Korea; Eu-min Jung, et. al. v. the Republic of Korea, Communication nos: 1593 to 1603/2007, 23 March 2010, CCPR/C/98/D/1593-1603/2007.

144. See Min-Kuy Jeong et. al. v. the Republic of Korea.

145. $R$ v. Immigration Appeal Tribunal and Secretary of State for the Home Department, ex parte Shah, [1997] Imm. A.R. 145; see also Goodwin v. the United Kingdom, Application no. 28957/ 9535, Eur. Comm'n H.R. Dec. \& Rep. 18 (2002), para. 74.

146. See Article 33 of the Refugee Convention. See also T. Malik, International Refugee Law: A Lexicon of Principles \& Issues (Bangladesh BarCouncil: Legal Education \& Training Institute, 1998), 80-2.

147. Soering v United Kingdom (1989) 11 EHRR 439, para. 87; See also Guy S. Goodwing-Gill, 'Refugees and their human rights', The RSC Working Paper Series 17 (2004): 4. 